\title{
Comparative Evaluation Research on the Carrying Capacity of Multi-regional Distribution Network Owner Project Departments Based on Combined Weights
}

\author{
Lin Jian ${ }^{1, *}$, Weng Xiaochun ${ }^{2}$, Yu Jing ${ }^{1}$, Yu Dingwen ${ }^{1}$, Zhang Zaiwei ${ }^{1}$ \\ ${ }^{1}$ State Grid Fujian Electric Power Co.,Ltd.economic and Technological Research Institute, Fuzhou, Fujian Province, China \\ ${ }^{2}$ State Grid Fujian Electric Power Co.,Ltd., Fuzhou, Fujian Province, China
}

\begin{abstract}
This paper proposes a comparative evaluation method for the carrying capacity of the owner's project department based on combined weights. This method first combines the current grid companies' requirements for the construction of the owner's project department and the current distribution network construction management issues to systematically construct the owner's project department's carrying capacity evaluation index system. Through comprehensive evaluation and collection of indicator-related data, it is determined based on the coefficient of variation method. The objective weight of the indicator is determined based on the analytic hierarchy process; then the integrated scoring model is used to comprehensively calculate the normalized indicator value and weight value to obtain the evaluation analysis result; finally, the method is verified by empirical analysis Effectiveness.
\end{abstract}

\section{Introduction}

In recent years, as the scale of distribution network construction continues to increase, the construction tasks continue to increase. Carrying out the analysis and evaluation of the carrying capacity of the owner's project department can further standardize the entire process management of the distribution network construction.

At present, there are relatively few literature references for the evaluation and analysis of the carrying capacity of the owner's project department. Literature ${ }^{[1]}$ constructed a carrying capacity analysis model from the aspect of the work intensity of the dispatching personnel of the power company to test the rationality of the dispatching personnel. Literature ${ }^{[2]}$ constructed a bearing capacity calculation model and established a research methodology of the normative system, which provided theoretical basis and practical experience for carrying out research on bearing capacity. Literature ${ }^{[3]}$ analyzed in detail the work carrying capacity of the front-line teams of power supply companies, and summarized the problems and optimization measures in the work carrying capacity of the teams. Literature ${ }^{[4]}$ conducts early-warning control of the carrying capacity and risk of subcontractors to meet the needs of rapid development of the power grid and the implementation of lean management. Literature ${ }^{[5]}$ is based on the application of the horizontal road map method, through the establishment of a calculation model, visual analysis of power construction management staffing, using objective data for review, providing data support for project risk management, so as to improve the rationality of staffing.
The above-mentioned documents provide certain methods and theoretical support for carrying out loadbearing evaluation, but they are not sufficiently integrated with the characteristics of distribution network management and management status. Therefore, starting from the characteristics of distribution network management and combining the owner's project department management specifications, this paper constructs a carrying capacity evaluation and analysis index system and evaluation method, and verifies the effectiveness of the model through empirical analysis. The specific research ideas of this paper are shown in Figure 1 below:

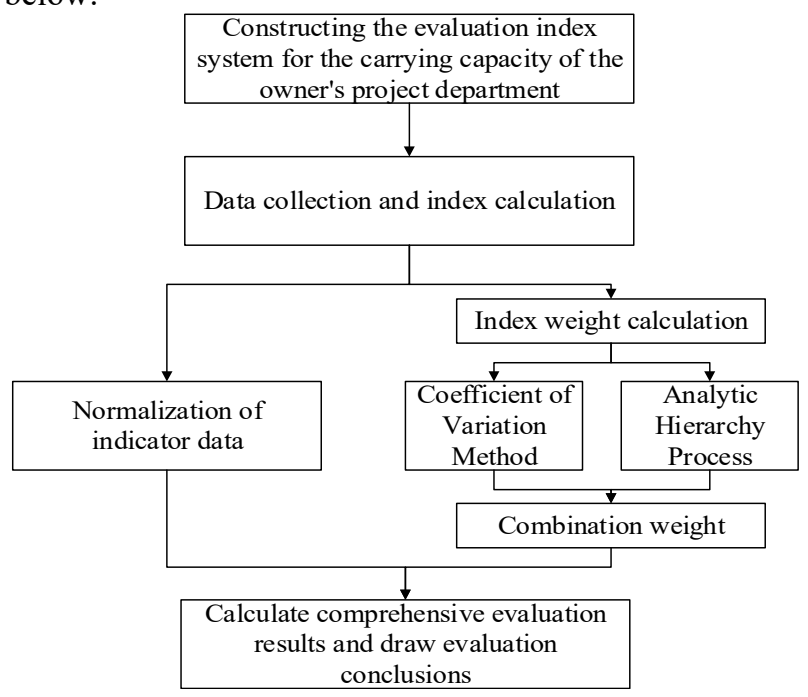

Fig 1. The research ideas of this article.

*Corresponding author's e-mail: 1182306191@ncepu.edu.cn 


\section{Construction of a comparative evaluation model for the carrying capacity of the project department of the distribution network owner}

\subsection{Construction of the evaluation index system for carrying capacity}

The construction of the evaluation index system for the carrying capacity of the owner's project department is based on the standardized management manual of the owner's project department of the distribution network project, the owner's project department's performance checklist and other normative system documents, from the dimensions of the owner's project department staffing and process management of the distribution network project. The design of the carrying capacity index focuses on the performance of the owner's project department in terms of the quality, schedule, and cost of the distribution network project. In order to comprehensively improve the operability and leadership of the evaluation work, the benchmarking index system is constructed as follows:

Table1. Carrying capacity evaluation index system of the owner's project department.

\begin{tabular}{|c|c|c|c|}
\hline $\begin{array}{c}\text { Serial } \\
\text { number }\end{array}$ & $\begin{array}{l}\text { First-level } \\
\text { index }\end{array}$ & $\begin{array}{l}\text { Secondary } \\
\text { indicators }\end{array}$ & $\begin{array}{l}\text { Three-level } \\
\text { indicators }\end{array}$ \\
\hline 1 & \multirow{5}{*}{$\begin{array}{l}\text { The } \\
\text { carrying } \\
\text { capacity } \\
\text { level of the } \\
\text { owner's } \\
\text { project } \\
\text { department }\end{array}$} & $\begin{array}{l}\text { Project } \\
\text { scale } \\
\text { carrying } \\
\text { capacity }\end{array}$ & $\begin{array}{c}\text { Investment } \\
\text { scale and staff } \\
\text { standard } \\
\text { support ratio }\end{array}$ \\
\hline 2 & & \multirow{2}{*}{$\begin{array}{l}\text { Personnel } \\
\text { capacity }\end{array}$} & $\begin{array}{c}\text { Project } \\
\text { manager's work } \\
\text { life support } \\
\text { ratio }\end{array}$ \\
\hline 3 & & & $\begin{array}{c}\text { Saturation of } \\
\text { qualifications } \\
\text { of project } \\
\text { department } \\
\text { personnel }\end{array}$ \\
\hline 4 & & $\begin{array}{c}\text { Foundation } \\
\text { bearing } \\
\text { capacity }\end{array}$ & $\begin{array}{l}\text { Milestone plan } \\
\text { implementation } \\
\text { rate }\end{array}$ \\
\hline 5 & & $\begin{array}{l}\text { Schedule } \\
\text { carrying } \\
\text { capacity }\end{array}$ & $\begin{array}{c}\text { Distribution } \\
\text { network project } \\
\text { completion rate } \\
\text { (total) }\end{array}$ \\
\hline
\end{tabular}

\begin{tabular}{|c|c|c|}
\hline 6 & & $\begin{array}{l}\text { Adjustment rate } \\
\text { of allocation } \\
\text { reform items }\end{array}$ \\
\hline 7 & & $\begin{array}{c}\text { "Four } \\
\text { Elements" } \\
\text { Match Rate }\end{array}$ \\
\hline 8 & $\begin{array}{c}\text { Safe } \\
\text { carrying } \\
\text { capacity }\end{array}$ & $\begin{array}{l}\text { Number of } \\
\text { personal safety } \\
\text { accidents }\end{array}$ \\
\hline 9 & $\begin{array}{l}\text { Mass } \\
\text { carrying } \\
\text { capacity }\end{array}$ & $\begin{array}{l}\text { Investment } \\
\text { deviation rate }\end{array}$ \\
\hline 10 & $\begin{array}{c}\text { Cost } \\
\text { bearing } \\
\text { capacity }\end{array}$ & $\begin{array}{l}\text { Time rate of } \\
\text { completion } \\
\text { settlement }\end{array}$ \\
\hline
\end{tabular}

\subsection{Evaluation weight determination}

\subsubsection{Principles and steps of analytic hierarchy process}

Analytic Hierarchy Process (Analytic Hierarchy Process for short AHP) first refines and decomposes the decisionmaking problem into different target layers, each of which represents an important part of the decision-making problem, and then combines the method of solving the judgment matrix according to the rating criteria and evaluation specifications, Calculate the feature vector to get the weight corresponding to each target layer element, and finally use the weighted sum method to calculate the final weight of each alternative plan corresponding to the total target, and the one with the largest weight is the optimal plan.

(1) First, build a hierarchical structure, decompose the decision-making problems in detail, and organize them into a top-to-bottom hierarchical structure. Complex problems are decomposed into multiple core elements. When applying AHP to analyze decision-making problems, the responsible problem is first decomposed into multiple elements, and then the elements are decomposed into several levels according to the attributes of the elements, and finally a hierarchical problem structure model is constructed as the basis of the analytic hierarchy process.

(2) Construct a judgment matrix In order to reflect the weight correspondence between each element, it is necessary to construct a judgment matrix. Generally, the 1-9 scale method is used, and the numbers 1-9 and its reciprocal are used as the scale to evaluate the correspondence between the elements.

(3) Single ranking consistency test Generally, the 
consistency index CI is used to test whether the judgment matrix is reasonable in design and whether there are logical errors. It is generally believed that when $\mathrm{CI}<0.10$, the judgment matrix is reasonable.

(4) Total ranking consistency test After the consistency of a single sort meets the requirements, the consistency test of the total sort is also required. If the test passes, the current weight ranking results can be used as the final decision basis.

\subsubsection{Coefficient of Variation Method}

The coefficient of variation method is a method to calculate the degree of change of the system indicators based on statistical methods, and is an objective weighting method. According to this method, the weight of the index with larger change difference is larger, and the weight of index with smaller change difference is smaller, so that the importance of the index is determined according to the statistical law of the index. The coefficient of variation method is a relatively objective method, which can objectively reflect the change information of the index data, and this method can obtain the weight of each index more objectively. Each indicator is weighted according to the degree of variation between the current value of each evaluation indicator and the target value. When the current value of each indicator has a large gap with the target value, it means that the indicator is difficult to achieve the target value and should be given a greater weight. Otherwise, it should be given a smaller weight.

(1) Assuming that there are n samples to be evaluated and $\mathrm{p}$ evaluation indicators, the original indicator data matrix is formed:

$$
\mathrm{X}=\left(\begin{array}{ccc}
x_{11} & \ldots & x_{1 \mathrm{p}} \\
\ldots & \ldots & \ldots \\
x_{\mathrm{n} 1} & \ldots & x_{\mathrm{np}}
\end{array}\right)
$$

(2) Calculate the mean and standard deviation of the jth evaluation index .

$$
\begin{aligned}
& \overline{x_{j}}=\frac{1}{n} \sum_{i=1}^{n} x_{i j} \\
& \mathrm{~s}_{\mathrm{j}}=\sqrt{\frac{\sum_{i=1}^{n}\left(x_{i j}-\overline{x_{j}}\right)^{2}}{n-1}}
\end{aligned}
$$

(3) Calculate the coefficient of variation of the $j$-th evaluation index.

$$
v_{j}=\frac{s_{j}}{\overline{x_{j}}}, \mathrm{j}=1,2,3 \ldots, \mathrm{p}
$$

(4) Normalize the coefficient of variation to obtain the weight of each indicator.

$$
\mathrm{w}_{\mathrm{j}}=\frac{v_{j}}{\sum_{j=1}^{p} v_{j}}
$$

\subsection{Determination of comprehensive evaluation results}

The linear model is selected to summarize the normalized index values of each index, and a comprehensive score is obtained:

$$
y=\sum_{j=1}^{m} w_{j} a_{j}
$$

$$
\sum_{j=1}^{m} w_{j}=1,0 \leq w_{j} \leq 1, j=1,2 \cdots m
$$

$y$ is the comprehensive score value of the system, $a_{j}$ is the normalized index value, and $w_{j}$ is the weight coefficient.

\section{Empirical analysis}

Select 9 municipal power supply companies under a

\begin{tabular}{|c|c|c|c|c|}
\hline \begin{tabular}{|c|}
$\begin{array}{c}\text { Serial } \\
\text { number }\end{array}$ \\
\end{tabular} & $\begin{array}{c}\text { Evaluation } \\
\text { index }\end{array}$ & $\begin{array}{c}\text { Objective } \\
\text { weight }\end{array}$ & $\begin{array}{c}\text { Subjective } \\
\text { weight }\end{array}$ & $\begin{array}{c}\text { Comprehensive } \\
\text { weight }\end{array}$ \\
\hline 1 & $\begin{array}{c}\text { Investment } \\
\text { scale and staff } \\
\text { standard } \\
\text { support ratio }\end{array}$ & 0.12 & 0.08 & 0.1 \\
\hline 2 & \begin{tabular}{|c|} 
Project \\
manager's work \\
life support \\
ratio
\end{tabular} & 0.14 & 0.08 & 0.1 \\
\hline 3 & $\begin{array}{c}\text { Saturation of } \\
\text { qualifications } \\
\text { of project } \\
\text { department } \\
\text { personnel } \\
\end{array}$ & 0.33 & 0.02 & 0.17 \\
\hline 4 & $\begin{array}{c}\text { Milestone plan } \\
\text { implementation } \\
\text { rate }\end{array}$ & 0.04 & 0.11 & 0.08 \\
\hline 5 & \begin{tabular}{|c|}
$\begin{array}{c}\text { Distribution } \\
\text { network project } \\
\text { completion rate } \\
\text { (total) }\end{array}$ \\
\end{tabular} & 0.08 & 0.09 & 0.09 \\
\hline 6 & $\begin{array}{l}\text { Adjustment } \\
\text { rate of } \\
\text { allocation } \\
\text { reform items }\end{array}$ & 0.04 & 0.14 & 0.09 \\
\hline 7 & $\begin{array}{c}\text { "Four } \\
\text { Elements" } \\
\text { Match Rate } \\
\end{array}$ & 0.06 & 0.14 & 0.10 \\
\hline 8 & $\begin{array}{c}\text { Number of } \\
\text { personal safety } \\
\text { accidents }\end{array}$ & 0 & 0.16 & 0.08 \\
\hline 9 & $\begin{array}{c}\text { Investment } \\
\text { deviation rate }\end{array}$ & 0.16 & 0.06 & 0.11 \\
\hline 10 & $\begin{array}{l}\text { Time rate of } \\
\text { completion } \\
\text { settlement }\end{array}$ & 0.03 & 0.12 & 0.08 \\
\hline
\end{tabular}
provincial power company as the research objects, collect relevant data, combine the coefficient of variation method and the analytic hierarchy process to get the corresponding subjective and objective weights and comprehensive weights. The results are shown in the following table.

Table2. Weight calculation results.

Combined with the above calculation company, the evaluation results of the carrying capacity of the project department of the distribution network owner in different regions are as follows. 
Table3. Comprehensive evaluation results.

\begin{tabular}{|c|c|c|c|c|c|c|c|c|c|}
\hline Company name & A & B & C & D & E & F & G & H & I \\
\hline Evaluation results & 0.8510 & 0.8712 & 0.8661 & 0.8973 & 0.9300 & 0.9292 & 0.8088 & 0.8668 & 0.9013 \\
\hline
\end{tabular}

According to the evaluation results, it can be seen that the carrying capacity level of $\mathrm{E}$ area is the most outstanding. The performance of indicators such as the investment scale and the standard support ratio of personnel, the support ratio of the project manager's working life, and the saturation of the qualifications of the project department personnel are all outstanding, and other indicators The performance is relatively balanced, so the evaluation result of the carrying capacity of the $\mathrm{E}$ area ranks first. In the follow-up, the advanced management experience of the $\mathrm{E}$ area must be further explored to improve the management level.

\section{Conclusion}

This paper proposes a comparative evaluation model based on combined weights for the carrying capacity of the owner's project department in a multi-regional distribution network. By combining the current management process, management status, and the current main assessment indicators, the carrying capacity level of the owner's project department is scientifically evaluated. It is helpful to standardize the whole process management of distribution network construction. Deeply implement the concepts of precise investment, safety and efficiency, promote the reform of the construction and management mode of the distribution network, and improve the efficiency of construction management. Provide grip and support for grid companies to cope with complex internal and external management situations.

\section{References}

1. Li Youliang, Chen Cunlin, Zhang Wei, Ye Haifeng, Liu Ludeng. Analysis and Suggestions on the Business Carrying Capacity of Electric Power Company Dispatchers[J]. Electric Power Safety Technology, 2018, 20(05): 17-20.

2. Yang Junxin, Wang Lisha, Chen Tielei, Tang Wei, Wen Huajing. Human resource management of substation maintenance enterprise oriented by carrying capacity[J]. Human Resources Development, 2015(20): 81-82.

3. $\mathrm{Xu}$ Mengjie. Analysis of the work carrying capacity of the front-line teams of power supply enterprises[J]. The World of Labor and Social Security (Theoretical Edition), 2013(09):231.

4. Zhang Chunxiang, Ma Changjiang. Discussion on the control mechanism of subcontractor's carrying capacity limitation[J]. Shandong Industrial Technology, 2019(08):238.

5. Shen Juemin. Analysis of the carrying capacity of the construction management personnel of the power infrastructure project based on the horizontal road map method[J]. Building Materials and Decoration, 2019(11): 235-237. 